\title{
Evaluation of measurements and calculation of primary production in the Dogger Bank area (North Sea) in summer 1988*
}

\author{
Roel Riegman ${ }^{1}$, Franciscus Colijn ${ }^{2}$ \\ ${ }^{1}$ Netherlands Institute for Sea Research, PO Box 59, 1790 AB Den Burg, The Netherlands \\ ${ }^{2}$ Tidal Waters Division, PO Box 20901, 2500 EX The Hague, The Netherlands
}

\begin{abstract}
Primary production was measured during a survey in the Dogger Bank area, where both stratified and non-stratified conditions existed in July-August 1988. Daily primary production was calculated, based on ${ }^{14} \mathrm{C}$-fixation rates in an incubator with an artificial light source, depth profiles of in situ irradiance, and vertically heterogeneous phytoplankton distributions. Values ranged among stations from 300 to $2200 \mathrm{mg} \mathrm{C} \mathrm{m} \mathrm{d}^{-1}$. Average primary production in the Dogger Bank area was estimated at $1.2 \mathrm{~g} \mathrm{C} \mathrm{m}^{-2} \mathrm{~d}^{-1}$. Variation in cloudiness affected primary production by a factor of 4.5 . Calculations based on surface samples alone showed an average areal primary production underestimate of $17 \%$. After correction for the uneven vertical biomass distribution, primary production was still underestimated by $12 \%$ as a result of photoadaptation. Especially below $30 \mathrm{~m}, \mathrm{I}_{\mathrm{k}}$ was reduced from 310 to $174 \mu \mathrm{E} \mathrm{m}^{-2} \mathrm{~s}^{-1}$, demonstrating the presence of shade-adapted phytoplankton at the thermocline. Calculated daily primary production rates based on in situ incubations and on incubator measurements deviated by only $5 \%$. Light quality did not have a significant effect on water column productivity. Sizedependent primary production based on post-incubation filtration onto $5 \mu \mathrm{m}$ filters showed that, on average, $84 \%$ of total primary production was in the $>5 \mu \mathrm{m}$ fraction.
\end{abstract}

\section{INTRODUCTION}

The importance of a reliable estimate of primary production in the North Sea has been recognized by various authors (Steele 1974, Jones 1984). From a literature survey on the references database 'Biosis Previews' 1969-1989 it can be concluded that only a limited amount of data has been published during the past 20 yr. Most plankton studies of this period (Fig. 1) were restricted to coastal zones such as the English coast ((2) \& (3), Ochocki et al. 1973), the Belgian coastal zone ((4), Lancelot \& Billen 1984) and the Dutch and German coastal zones ((5), Mommaerts 1973; (6), Veldhuis et al. 1986; (7), Gieskes \& Kraay 1977; (8), Cadée 1986; (11), Colijn et al. 1990). Along the German coast (Sylt) primary production measurements were reported by Asmus \& Asmus 1985 (12). Offshore studies are even more scarce ((1), Gieskes \& Kraay 1980; (9), Gieskes \& Kraay 1984, Tijssen \& Wetsteyn 1984). The lack of sufficient year-round data and the unequal attention

\footnotetext{
- Publication no. 19 of the project Applied Scientific Research Netherlands Institute for Sea Research (BEWON)
}

that has been paid to the different hydrographic regimes in the North Sea (indicated by the dotted lines in Fig. 1) preclude the calculation of a reliable primary production estimate. This lack of data is mainly due to the size of the North Sea and the unfavourable weather during autumn and winter. Moreover, a preference for coastal zone studies is stimulated by the frequent recognition of eutrophication effects in coastal regions.

The main purpose of this study was to evaluate a simple and fast method which could enable monitoring of primary production over large areas over a short period of time. The measurements were made during July 1988 in the Dogger Bank area. No measurements on primary production had been made in this area previously. Estimation of primary production from ${ }^{14} \mathrm{C}$ incubation data yields a value somewhere between gross and net production (Peterson 1980).

The phytoplankton in the North Sea is distributed very heterogeneously due to variations in physical and chemical factors (Braarud et al. 1953, Gieskes \& Kraay 1977. Creutzberg 1985). Consequently, spatial variation in primary production was to be expected. To collect as much data as possible, preference was given 


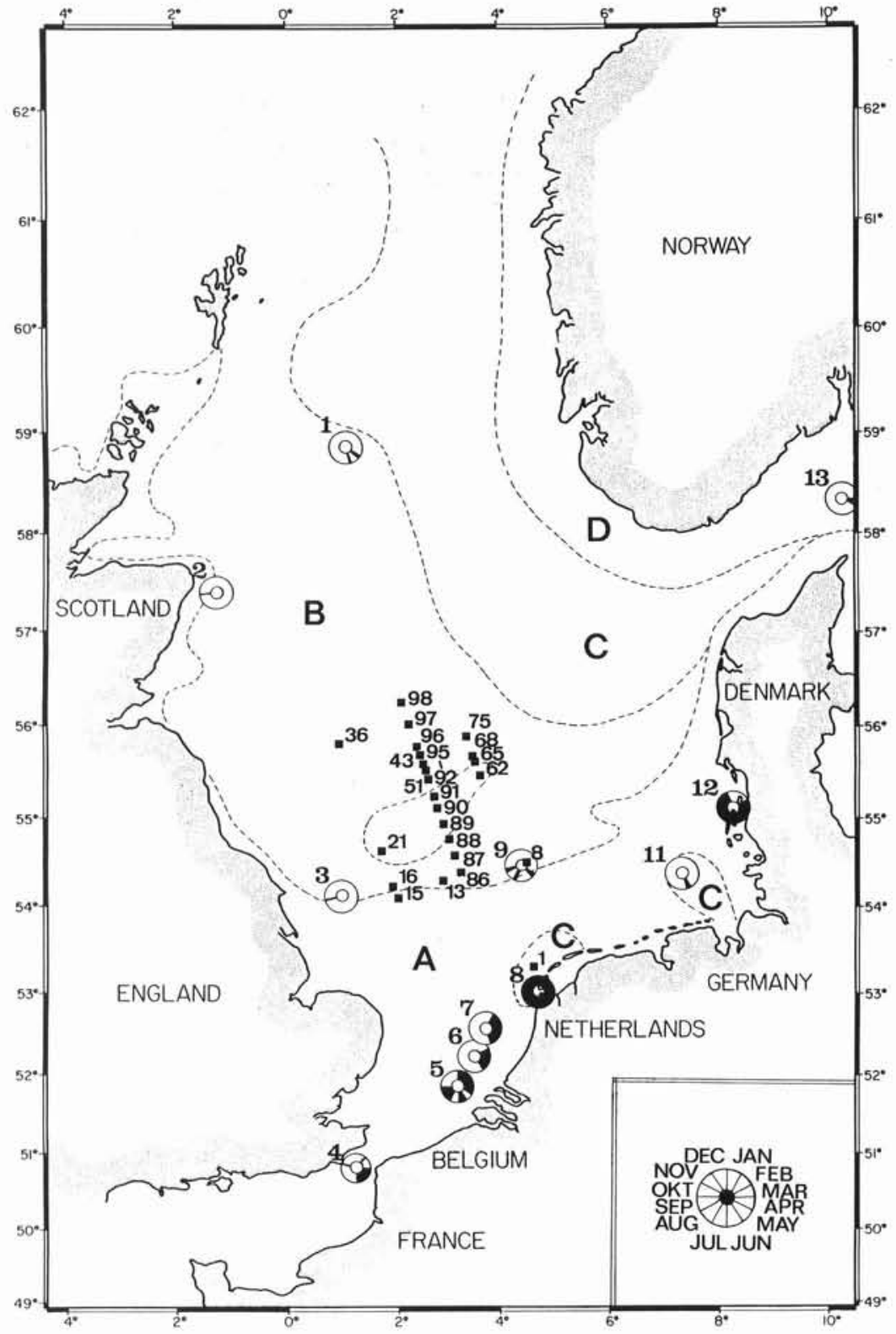

Fig. 1. Locations of published primary production studies (references in text). Black shading in rings indicates measuring period. (*) Sampling stations of present study. Dotted lines indicate borders between different water regimes after Dietrich (1950): (A) homohaline and homothermal throughout the whole year; (B) seasonal thermal stratification in homohaline water; (C) seasonal thermal stratification and permanent (weak) haline stratification; (D) permanent strong haline stratification

to short-term (i.e. 2 h) ${ }^{14} \mathrm{C}$-incubations. Production profiles were estimated from production-irradiance (P-I) relationships and the vertical distribution of fluorescence and irradiance. These profiles were compared with in situ incubations. Also, the effect of spectral distribution on daily primary production estimates and the relative importance of primary producers smaller than $5 \mu \mathrm{m}$ was studied.

\section{MATERIAL AND METHODS}

The sampling locations are shown in Fig. 1. At some stations more than one production profile was measured within $24 \mathrm{~h}$ to obtain insight into possible diel changes in photosynthetic characteristics of watermasses drifting past the ship. A S-N transect over the Dogger Bank was completed within $1 \mathrm{~d}$. These stations included a completely mixed situation (Stns $89 \& 90$ ) and 2 stratified situations (Stns 86 to $88 \& 91$ to 98 ). Samples for the determination of ${ }^{14} \mathrm{C}$-fixation rates were taken from at least 2 depths: at $5 \mathrm{~m}$ and at the chlorophyll fluorescence maximum around the thermocline, if present. Where fluorescence was homogeneously distributed the second sample was taken at $5 \mathrm{~m}$ above the sea floor. In 1988, our Niskin sampler was equipped with a rubber cord. Its inhibitory effect on carbon fixation measurements has been reported recently (Williams \& Robertson 1989) for oligotrophic phytoplankton during long-term $(>6 \mathrm{~h})$ incubations. In our study much shorter incuba- 
tion times $(2 \mathrm{~h})$ were used. P-I relationships were measured in an incubator at 5 irradiances, ranging from about 2500 to $25 \mu \mathrm{E} \mathrm{m}^{-2} \mathrm{~s}^{-1}$, for $2 \mathrm{~h}$ after the addition of 5 $\mu \mathrm{Ci} \mathrm{NaH}{ }^{14} \mathrm{CO}_{3}$ (Carrierfree, Amersham, USA) to $50 \mathrm{ml}$ subsamples. The incubator was illuminated with an Osram metallogen HMI 1200 W lamp (Colijn 1983). Different irradiances were achieved by neutral density filters (Lee, Andover, England) covering the polystyrene tissue culture bottles (Greiner, Solingen, Germany). Prior to every incubation, incubator irradiances were measured with a Licor underwater Quantum sensor LI192 SA. From these measurements the irradiance was calculated for each bottle. After incubation the samples were filtered onto Sartorius membrane filters (SM $11306,0.45 \mu \mathrm{m})$ at reduced differential pressure $(<100$ $\mathrm{mm} \mathrm{Hg}$ ). Filters were then acid-fumed for at least $5 \mathrm{~min}$ and counted in a liquid scintillation counter after addition of $10 \mathrm{ml}$ Instagel (Packard, USA). The incubation bottles were cleaned with and left in Whatman GF/F filtered surface seawater between experiments. Prior to use they were flushed with at least 3 times their volume of the seawater sample. A separate series of bottles was used for surface samples which were expected to have low nutrient concentrations in order to avoid any possible contamination with nutrients. Calculation of Cfixation rates was based on the initial amount of label added, whereas a constant value of $24 \mathrm{mg} \mathrm{Cl}^{-1}$ for total inorganic carbon was assumed. Dark uptake values were not subtracted from light values (Mortain-Bertrand et al. 1988). In general dark values did not exceed $5 \%$ of the $\mathrm{P}_{\max }$ value. P-I curves were fitted according to Platt et al. 1980 (cf. Colijn 1983) using the procedure algorithm EO4FDF from the library of Numerical Algorithms Group (NAG) (Anonymous 1987) which enabled a simultaneous and independent estimate (Gill \& Murray 1978) of the maximum photosynthetic rate $\left(\mathrm{P}_{\max }\right)$, the affinity of photosynthesis for light $(\alpha)$, the inhibition constant $(\beta)$ and $\mathrm{I}_{\mathrm{k}}$ (the ratio between $\mathrm{P}_{\max }$ and $\alpha$ ). During the whole period incident solar irradiance was measured on board using a Kipp solarimeter. From the average daily irradiance the photosynthetically active radiation (PAR) was calculated assuming PAR to be $45 \%$ of the total irradiance, expressed as $\mathrm{J} \mathrm{m}^{-2} \mathrm{~s}^{-1}$ (Lüning 1981). Light reflection at the sea surface was assumed to be $3 \%$ of total irradiance (Jerlov 1968). The underwater attenuation coefficient $\left(\mathrm{K}_{\mathrm{d}}\right.$ in $\left.\mathrm{m}^{-1}\right)$ was calculated from underwater quantum measurements and fitted according to the Lambert-Beer law. At some stations $\mathrm{K}_{\mathrm{d}}$ was found to vary with depth. At stations where sampling occurred during the night $\mathrm{K}_{\mathrm{d}}$ was estimated from turbidity measurements using a relationship between light attenuation and turbidity established during the cruise. To optimize an estimated production profile the watercolumn was divided in 2 to 4 segments, depending on the variation in vertical fluorescence distribution, in such a way that each water sample represented the entire segment. Fluorescence profiles were used to correct the calculated production profiles for a non-homogeneous distribution of algal biomass within each segment. At 2 stations an extensive comparison of in situ and incubator measurements could be achieved over a whole day.

Chlorophyll concentrations were determined by fluorometry on acetone extracts of particulate matter collected on Whatman GF/C filters and standardized against commercially available chlorophyll a (isolated from spinach; Sigma, USA).

At a few stations post-incubation filtration (cellulose nitrate filters; Sartorius, Germany) was performed to compare primary production in the $>5 \mu \mathrm{m}$ with the small fraction between 0.45 and $5 \mu \mathrm{m}$.

At 2 stations (68 and 75) $24 \mathrm{~h}$ studies were performed: sampling at a time interval of about $6 \mathrm{~h}$ should give insight into possible diel variation of photosynthetic characteristics per se and within watermasses drifting past the ship.

The effect of light quality was checked on depth samples from 3 stations: 51, 62 and 75. Incubations were performed in series with neutral density filters and series equipped with 2 different cuvettes containing separated solutions of $\mathrm{FeCl}_{3}$ and $\mathrm{CuSO}_{4}$ with a known specific absorption spectrum (measured with a spectrophotometer). The concentration of these solutions was calculated, using a special designed computer program, in such a way that the combination of both liquid filters allowed an optimum approximation of the in situ spectral light distribution. The in situ spectral light distribution at the sampling depth was measured using a spectral irradiance meter (Spitzer \& Wernand 1986).

\section{RESULTS}

Information on the sampling stations is presented in Table 1. In agreement with earlier reports on offshore areas (Gieskes \& Kraay 1984, Creutzberg 1985) summer chlorophyll a values in the surface layers were low: mean $0.65 \mu \mathrm{g}^{-1}$. Only the coastal station (Stn 1) showed a very high value. The stratified stations showed a deep chlorophyll a maximum with 5- to 10fold higher values compared to the surface concentration. This maximum was present at the thermocline where the nitrogen-depleted, warmer upper layer (15 $\pm 1^{\circ} \mathrm{C}$ ) was separated from the nutrient-rich, cold lower layer $\left(6\right.$ to $\left.8^{\circ} \mathrm{C}\right)$. More detailed information on nutrient levels and temperature distribution is presented elsewhere (Riegman et al. 1990).

The vertical attenuation coefficient varied between 0.06 and $0.15 \mathrm{~m}^{-1}$ (Stn 1: $0.41 \mathrm{~m}^{-1}$ ) with an average of 
Table 1. Compilation of data from all primary production stations. Attenuation coefficient $\mathrm{K}_{\mathrm{d}}$ in $\mathrm{m}^{-1}$. The presence of stratification was concluded from the vertical temperature distribution. Values from subsurface samples (5 m) are given for chlorophyll a $\left(\mu \mathrm{g} \mathrm{l}^{-1}\right) ; \mathrm{P}_{\max }\left(\mathrm{mg} \mathrm{C} \mathrm{m}^{-3} \mathrm{~h}^{-1}\right)$ and $\alpha\left(\mathrm{mg} \mathrm{C} \mathrm{m}^{-3} \mathrm{~h}^{-1}\left[\mu \mathrm{E} \mathrm{m}^{-2} \mathrm{~s}^{-1}\right]^{-1}\right)$. Primary production (PP) in $\mathrm{g} \mathrm{C} \mathrm{m}^{-2} \mathrm{~d}^{-1}$ is calculated for a 'standard' day

\begin{tabular}{|c|c|c|c|c|c|c|c|c|c|}
\hline $\begin{array}{l}\text { Date } \\
(1988)\end{array}$ & Station & $\begin{array}{c}\text { Time } \\
\text { (h) }\end{array}$ & $\begin{array}{l}\text { Depth } \\
\text { (m) }\end{array}$ & Stratification & $\mathrm{K}_{\mathrm{d}}$ & Chl a & $\mathrm{P}_{\max }$ & $\alpha$ & PP \\
\hline $14 \mathrm{Jul}$ & 1 & $12: 00$ & 22 & + & 0.41 & 13.01 & 76.1 & 0.124 & 1.76 \\
\hline $15 \mathrm{Jul}$ & $8 a$ & $12: 00$ & 45 & + & 0.07 & 0.46 & 7.3 & 0.016 & 1.38 \\
\hline 6 Aug & $8 b$ & $12: 00$ & 45 & - & 0.12 & 2.10 & 36.6 & 0.084 & 3.49 \\
\hline $16 \mathrm{Jul}$ & 13 & $12: 00$ & 44 & + & 0.07 & 0.93 & 8.1 & 0.017 & 1.36 \\
\hline 5 Aug & $15 a$ & $6: 00$ & 32 & - & 0.15 & 1.9 & 17.0 & 0.042 & 1.80 \\
\hline 5 Aug & $15 b$ & $13: 00$ & 32 & - & 0.15 & 1.2 & 13.2 & 0.045 & 2.04 \\
\hline $17 \mathrm{Jul}$ & 16 & $12: 00$ & 77 & + & 0.08 & 0.61 & 3.4 & 0.023 & 1.45 \\
\hline $18 \mathrm{Jul}$ & $21 \mathrm{a}$ & $12: 00$ & 27 & - & 0.13 & 0.90 & 3.7 & 0.017 & 1.69 \\
\hline 4 Aug & $21 b$ & $12: 00$ & 27 & - & 0.12 & 0.43 & 10.3 & 0.042 & 0.89 \\
\hline $19 \mathrm{Jul}$ & 36 & $12: 00$ & 77 & + & 0.07 & nd & 3.2 & 0.012 & 1.40 \\
\hline 3 Aug & $43 a$ & $6: 00$ & 50 & + & 0.08 & 0.26 & 6.8 & 0.017 & 1.60 \\
\hline 3 Aug & $43 b$ & $13: 00$ & 50 & + & 0.08 & 0.24 & 8.6 & 0.020 & 1.69 \\
\hline $20 \mathrm{Jul}$ & 51 & $12: 00$ & 34 & + & 0.06 & 0.24 & 3.2 & 0.009 & 0.85 \\
\hline $21 \mathrm{Jul}$ & 62 & $12: 00$ & 27 & + & 0.10 & 0.13 & 6.6 & 0.020 & 0.97 \\
\hline $21 \mathrm{Jul}$ & 65 & $16: 00$ & 30 & + & 0.11 & 0.59 & 6.4 & 0.019 & 1.00 \\
\hline $28 \mathrm{Jul}$ & $68 a$ & 00:00 & 33 & + & 0.13 & 0.30 & 2.7 & 0.016 & 0.37 \\
\hline $30 \mathrm{Jul}$ & $68 \mathrm{~b}$ & $12: 00$ & 33 & + & 0.13 & 0.74 & 7.6 & 0.028 & 1.49 \\
\hline $30 \mathrm{Jul}$ & $68 c$ & $16: 00$ & 33 & + & 0.13 & 0.48 & 6.8 & 0.037 & 2.64 \\
\hline $30 \mathrm{Jul}$ & $68 d$ & $24: 00$ & 33 & + & 0.13 & 0.81 & 3.9 & 0.034 & 0.89 \\
\hline 27 Jul & $75 a$ & $8: 00$ & 50 & + & 0.08 & 0.24 & 4.6 & 0.025 & 1.28 \\
\hline $27 \mathrm{Jul}$ & $75 b$ & $13: 30$ & 50 & + & 0.08 & 0.20 & 2.8 & 0.015 & 0.71 \\
\hline $27 \mathrm{Jul}$ & $75 c$ & $19: 00$ & 50 & + & 0.08 & 0.19 & 3.9 & 0.012 & 0.42 \\
\hline $27 \mathrm{Jul}$ & $75 d$ & $24: 00$ & 50 & + & 0.08 & 0.17 & 2.4 & 0.022 & 0.87 \\
\hline $22 \mathrm{Jul}$ & $75 \mathrm{e}$ & $00: 00$ & 50 & + & 0.08 & 0.44 & 6.4 & 0.022 & 0.81 \\
\hline $31 \mathrm{Jul}$ & 86 & $24: 00$ & 41 & + & 0.08 & 0.56 & 3.8 & 0.026 & 1.26 \\
\hline $1 \mathrm{Aug}$ & 87 & $2: 00$ & 41 & + & 0.12 & 1.60 & 7.8 & 0.049 & 1.60 \\
\hline 1 Aug & 88 & $4: 00$ & 34 & + & 0.12 & 0.97 & 3.9 & 0.027 & 0.89 \\
\hline 1 Aug & 89 & $6: 00$ & 22 & - & 0.13 & 1.59 & 12.2 & 0.070 & 2.03 \\
\hline $1 \mathrm{Aug}$ & 90 & $8: 00$ & 22 & - & 0.15 & 0.79 & 7.3 & 0.031 & 0.86 \\
\hline $1 \mathrm{Aug}$ & 91 & $10: 00$ & 27 & + & 0.15 & 0.88 & 7.7 & 0.040 & 1.48 \\
\hline $1 \mathrm{Aug}$ & 92 & $12: 00$ & 32 & + & 0.10 & 0.33 & 6.1 & 0.020 & 1.27 \\
\hline $1 \mathrm{Aug}$ & 93 & $14: 00$ & 36 & + & 0.08 & 0.4 & 3.6 & 0.012 & 1.22 \\
\hline $1 \mathrm{Aug}$ & 94 & $16: 00$ & 38 & + & 0.08 & 0.45 & 6.6 & 0.018 & 1.17 \\
\hline $1 \mathrm{Aug}$ & 95 & $18: 00$ & 54 & + & 0.09 & 0.50 & 13.4 & 0.012 & 1.03 \\
\hline $1 \mathrm{Aug}$ & 96 & $20: 00$ & 69 & + & 0.10 & 0.66 & 10.7 & 0.019 & 1.12 \\
\hline $1 \mathrm{Aug}$ & 97 & $22: 00$ & 82 & + & 0.08 & 0.41 & 2.8 & 0.013 & 0.79 \\
\hline $1 \mathrm{Aug}$ & 98 & $24: 00$ & 84 & + & 0.07 & 0.17 & 1.1 & 0.008 & 0.33 \\
\hline
\end{tabular}

$0.10 \mathrm{~m}^{-1}$. Total daily irradiance (TDI) ranged from 2694 $\mathrm{kJ} \mathrm{m}^{-2}$ to $25414 \mathrm{~kJ} \mathrm{~m}^{-2}$. Over the whole survey period the average value of TDI was $15760 \mathrm{~kJ} \mathrm{~m}^{-2}$. This is referred to as the 'standard' day.

Daily primary production (in $\mathrm{g} \mathrm{C} \mathrm{m}^{-2} \mathrm{~d}^{-1}$ ) was calculated for the actual (A) daily irradiance (irradiance of sampling day), but also for the average (B) irradiance during the survey period (an average summer period, the 'standard' day), and - to check daily variability due to irradiance differences - for the days with maximal (C) and minimal (D) irradiance. Actual daily primary production ranged from 0.3 to well over $2.0 \mathrm{~g} \mathrm{C} \mathrm{m}^{-2}$; primary production on the 'standard' day (B) ranged from 0.4 to over $3 \mathrm{~g} \mathrm{C} \mathrm{m}^{-2}$. Method $\mathrm{C}$ gave results ranging from 0.4 to $4.5 \mathrm{~g} \mathrm{C} \mathrm{m}^{-2}$ whereas Method D gave very low productivities ranging from 0.1 to $1.3 \mathrm{~g} \mathrm{C}$ $\mathrm{m}^{-2}$. Average values over 37 measurements were 1.16, $1.29,1.68$ and 0.37 for Methods A, B, C, and D, respectively. This underlines the preponderant influence of irradiance on long-term primary production. In stratified waters an average value of $1.06 \mathrm{~g} \mathrm{C} \mathrm{m}^{-2} \mathrm{~d}^{-1}$ at an average chlorophyll a subsurface concentration of $0.50 \mu \mathrm{g} \mathrm{l}^{-1}$ was found. In completely mixed waters these values were higher, viz. $1.49 \mathrm{~g} \mathrm{C} \mathrm{m}^{-2} \mathrm{~d}^{-1}$ and $1.27 \mu \mathrm{g} \mathrm{chl} \mathrm{a} \mathrm{l}^{-1}$ (coastal Stn 1 was excluded from the calculation). Clearly the differences in chlorophyll a concentration were less strongly reflected in the daily primary production. In both types of watermasses a 

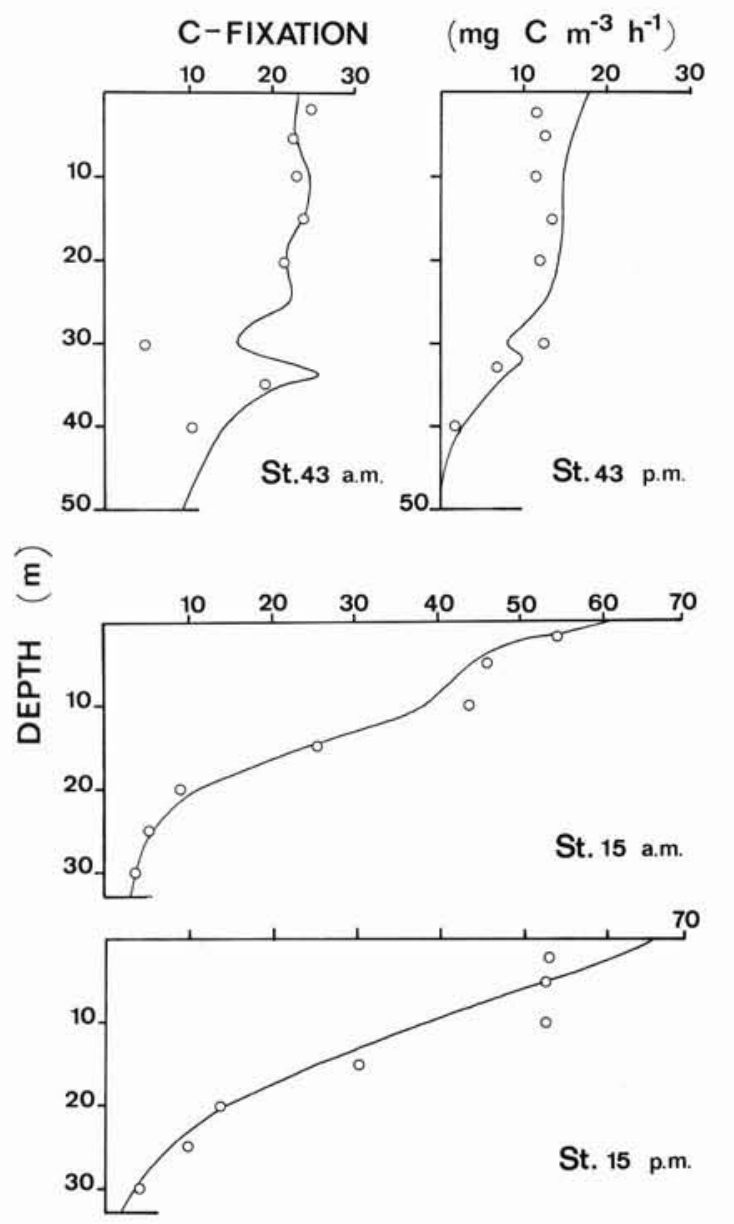

Fig. 2. Vertical distribution of primary production at the wellmixed Stn 15 and at the stratified Stn 43. Incubator method A $(\longrightarrow)$ was compared with in situ measurements $(0)$ from 6:00 to $13: 00$ h ('a.m.') and from 13:00 to $20: 00$ h ('p.m.')

'standard day' primary production of $>1 \mathrm{~g} \mathrm{C} \mathrm{m}^{-2} \mathrm{~d}^{-1}$ could be reached easily. Subsequently, 3 other methods were used to calculate daily primary production with the following assumptions: in Method E, calculation was based on incubation of the surface sample only (instead of a second sample from the thermocline), but with a biomass correction by means of the fluorescence profiles; in Method F, the same procedure was followed but without a biomass correction; and finally, to study the effect of inhibition (Method G), the inhibition factor ( $\beta$ ) in Platt's formulation was set to zero. The results of these calculations (using the irradiance of a 'standard' day) showed that the average values from Methods E, F and G were respectively $1.13,1.07$ and $1.59 \mathrm{~g} \mathrm{C} \mathrm{m}^{-2} \mathrm{~d}^{-1}$. These results imply that primary production values based on incubation of surface samples only and without a biomass correction would underestimate total water column production by 10 to $20 \%$ in these waters during this time. If light inhibition is not incorporated in the
Table 2. Average values and standard deviation of photosynthetic parameters from samples taken between 0 and $15 \mathrm{~m}$, 15 to $30 \mathrm{~m}$, and $>30 \mathrm{~m}$ at the various sampling stations, $\mathrm{P}_{\text {max }}^{\mathrm{b}}$ in $\mathrm{mg} \mathrm{C}(\mathrm{mg} \mathrm{chl} a)^{-1} \mathrm{~h}^{-1} ; \alpha^{\mathrm{b}}$ in $\mu \mathrm{g} \mathrm{C}(\mathrm{mg} \mathrm{chl} a)^{-1} \mathrm{~h}^{-1}\left(\mu \mathrm{E} \mathrm{m} \mathrm{m}^{-2}\right.$ $\left.\mathrm{s}^{-1}\right)^{-1}$ and $\mathrm{I}_{\mathrm{k}}$ in $\mu \mathrm{E} \mathrm{m}^{-2} \mathrm{~s}^{-1}$. Number of samples in brackets

\begin{tabular}{|lccc|}
\hline \multicolumn{1}{l}{$\begin{array}{l}\text { Depth } \\
\text { category }\end{array}$} & $\mathrm{P}_{\max }^{\mathrm{b}}$ & $\alpha^{\mathrm{b}}$ & $\mathrm{I}_{\mathrm{k}}$ \\
\hline $0-15 \mathrm{~m}$ & $13.8 \pm 11(36)$ & $46.4 \pm 23(37)$ & 297 \\
$15-30 \mathrm{~m}$ & $13.6 \pm 10(25)$ & $42.0 \pm 25(29)$ & 323 \\
$>30 \mathrm{~m}$ & $5.9 \pm 3.4(28)$ & $34.0 \pm 12(29)$ & 174 \\
$0-30 \mathrm{~m}$ & $1.5 \pm 0.7(7)$ & $8.2 \pm 3.8(7)$ & 183 \\
$<5 \mu \mathrm{m}$ & & & \\
\hline
\end{tabular}

calculations primary production is overestimated by ca $25 \%$. At 2 stations, 2 consecutive half-day in situ incubations were performed with samples suspended from a drift buoy (Fig. 2). For all 4 incubations we observed good agreement between values calculated from P-I relations and those measured in situ, with no consistent deviation for one method or the other. On average the total column production estimated from the incubator method was $5 \%$ higher than the estimate from the in situ incubations.

In Table 2 the physiological parameters $\left(\mathrm{P}^{\mathrm{b}}{ }_{\max }, \alpha^{\mathrm{b}}\right.$ and $I_{k}$ ) obtained from the fits of the P-I curves are summarized. These data show that $\mathrm{P}^{\mathrm{b}}{ }_{\max }$ and $\mathrm{I}_{\mathrm{k}}$ are fairly constant within the upper $30 \mathrm{~m}$ of the water column but decrease in the samples taken at greater depth. This decrease is due to photoadaptation to low irradiance in the deeper layers, but is probably also due to a different species composition in the subthermocline layers, with a dominance of Ceratium spp. (unpubl.). Obviously the $<5 \mu \mathrm{m}$ fraction is low-light adapted, but aberrant in its physiology because of its reduced $\mathrm{P}_{\text {max }}^{\mathrm{b}}$. Also its photosynthetic efficiency $\left(\alpha^{\mathrm{b}}\right)$ is 5 times lower than that of the total fraction.

At 3 stations the effect of the spectral distribution of light on photosynthesis was studied. Incubation with white light resulted in almost a doubling of the $P_{\max }$ values and a reduction of the photosynthetic efficiency $(\alpha)$ compared to incubation with blue-green light (Table 3). At these sampling depths non-saturating irradiances prevail. Therefore, the reduction of $\alpha$ induced by the use of neutral density instead of coloured filters would have the largest impact on photosynthesis estimation. However, it appeared that the impact on the estimates of total primary production of the entire water column was negligible (Table 3). This was mainly because most of the primary production occurred in the upper part of the photic zone.

The results of post-incubation filtration into 2 fractions are summarized in Table 4 . On average $84 \%$ of the daily primary production was found in the $>5 \mu \mathrm{m}$ fraction. Stns 36 and 75 showed the highest contribu- 
Table 3. Effect of light quality on photosynthetic parameters (same units as in Table 2) and estimated primary production of the water column (in $\mathrm{g} \mathrm{C} \mathrm{m}^{-2} \mathrm{~d}^{-1}$ )

\begin{tabular}{|c|c|c|c|c|c|c|c|}
\hline \multirow[t]{2}{*}{ Station } & \multirow{2}{*}{$\begin{array}{l}\text { Sampling } \\
\text { depth (m) }\end{array}$} & \multicolumn{3}{|c|}{ 'White' light } & \multicolumn{3}{|c|}{ 'Blue-green' light } \\
\hline & & $\mathrm{P}_{\max }^{\mathrm{b}}$ & $\alpha^{\mathrm{b}}$ & PP & $\mathrm{P}_{\text {max }}^{\mathrm{b}}$ & $\alpha^{\mathrm{b}}$ & PP \\
\hline 51 & 26 & 13.1 & 28.2 & 0.85 & 7.0 & 31.3 & 0.87 \\
\hline 62 & 24 & 32.7 & 139.0 & 0.97 & 17.1 & 183.2 & 0.99 \\
\hline $75 \mathrm{e}$ & 28 & 3.9 & 23.8 & 0.79 & 2.3 & 37.9 & 0.80 \\
\hline
\end{tabular}

tion of the $<5 \mu \mathrm{m}$ fraction; both these stations are in the stratified region of the surveyed area. The completely mixed stations $(8 b, 13$ and 21) showed the lowest contribution of the $<5 \mu \mathrm{m}$ fraction in the daily primary production.

\section{DISCUSSION}

Small-scale patchiness of phytoplankton distribution and productivity was illustrated by the strong fluctuations observed at a single station within $24 \mathrm{~h}$ (Stns $68 \mathrm{a}-\mathrm{d}$ and $75 \mathrm{a}-\mathrm{d}$; Table 1 ). This patchiness, created by, among other things, the complex hydrodynamics of the area and the irregular occurrence of wind mixing, emphasizes the need for a measurement technique that allows a high frequency of sampling. The in situ method is probably the most reliable and realistic method of incubation (Jitts 1963, Sorokin \& Konovalova 1973) but has very limited practical applicability for sea-going survey operations. The alternative method, where samples are incubated in a gradient of natural sunlight in deck boxes on board ship (simulated in situ method; originally described by Steemann Nielsen in 1957 ) is widely used in marine primary production

Table 4. Size-dependent daily primary production based on postincubation filtration over 5.0 and $0.45 \mu \mathrm{m}$ filters as \% of total daily column primary production

\begin{tabular}{|ccr|}
\hline \multicolumn{3}{|c|}{$\%$ of total primary production } \\
Station & $>5 \mu \mathrm{m}$ & $<5 \mu \mathrm{m}$ \\
\hline 1 & 88 & 12 \\
8 & 96 & 4 \\
$8 \mathrm{a}$ & 84 & 16 \\
13 & 91 & 9 \\
16 & 88 & 12 \\
$21 \mathrm{a}$ & 82 & 16 \\
$21 \mathrm{~b}$ & 86 & 14 \\
36 & 73 & 27 \\
51 & 80 & 20 \\
62 & 84 & 16 \\
65 & 84 & 16 \\
$75 \mathrm{e}$ & 77 & 23 \\
Average & 84 & 16 \\
\hline
\end{tabular}

studies. This method is less suitable for the North Sea because of the strong fluctuations in weather conditions. Variation in cloudiness affects the primary production dramatically. Comparison between fully clouded conditions (calculation Method D) and unclouded wheather (calculation Method C) shows primary production to vary by a factor 4.5 due to incident irradiance alone. This implies that variations in cloudiness during a cruise will introduce artificial differences in the productivity of different areas, if weather conditions change dramatically during the period of the cruise. After a longer period (i.e. several days or longer) of continuous bad weather, these artificial differences might become less severe due to photoadaptation or selection towards shade-adapted species. Our study shows that an artificial light source should be used when the main purpose of primary production measurements is to compare the productivity of different areas. The measurement capacity of the present method could be doubled if only surface samples were taken. On the other hand an underestimate of $12 \%$ was made if only P-I relationships of surface samples were used to calculate the column productivity but with a correction for non-homogeneous plankton distribution on the basis of fluorescence profiles. The underestimation is mainly due to the optimalisation of the photosynthesis parameters (photoadaptation) of phytoplankton at greater depth (Table 2). Especially in stratified areas with a deep chlorophyll maximum, the omission of the correction for non-homogeneous phytoplankton distribution will lead to serious underestimation. For the stratified locations around the Dogger Bank this underestimation was $18 \%$.

On-deck incubations with varying irradiance do not permit the calculation of photosynthetic parameters. The present method has the advantage of allowing both the incorporation of total daily irradiance and information on photosynthetic parameters. The latter can be used for modelling purposes (Harrison et al. 1985, Smith et al. 1987) and, especially in combination with remote sensing data, would enable a more synoptic estimate to be made (Platt et al. 1988).

When samples are taken at different depths, $\mathrm{P}_{\max }$ and $\alpha$ can provide information on the vertical stability of the water column (Cullen \& Lewis 1988). During the cruise 
2 storms occurred successively (maximum wind speed $25 \mathrm{~m} \mathrm{~s}^{-1}$ for at least $48 \mathrm{~h}$ ). Changes in temperature profiles indicated enhancement of the mixing depth from $20 \mathrm{~m}$ to about $30 \mathrm{~m}$. The effect is reflected in the results presented in Table 2: on average samples taken between 15 and $30 \mathrm{~m}$ depth did not deviate significantly from the surface samples with respect to $P_{\max }$ and $\alpha$. At greater depths shade-adapted phytoplankton was present, as can be concluded from their lower $I_{k}$ values. The presented $P_{\max }$ values fall in the upper range of former published data on marine phytoplankton (Eppley 1972). This can be attributed to the fitting procedure ('Material and Methods'). The equation of Platt et al. (1980) implicitly assumes that photoinhibition also occurs at a light intensity where production is at a maximum. This explains the difference between the actual measured $\mathrm{P}_{\max }$ values (being on average $43 \%$ lower) and the calculated $\mathrm{P}_{\max }$ values (presented in Tables 2 \& 3).

At all 3 stations a stimulating effect of blue-green light on photosynthesis was observed. A higher photosynthetic efficiency under blue-green light has been reported for a large number of species (Wallen \& Geen 1971, Glover et al. 1987, Prézelin et al. 1989). However, in samples from the Sargasso Sea, Prézelin et al. (1989) observed no such effect on $\mathrm{P}_{\max }$. With respect to the Sargasso Sea, where the average depth of the euphotic zone was $140 \mathrm{~m}$, Prézelin et al. showed that the daily integrated water-column primary production would be 6 to $13 \%$ higher with blue-green light instead of white light estimates. Around the Dogger Bank the average depth of the euphotic zone ( $1 \%$ level) was much less: $46 \mathrm{~m}$. The use of neutral density filters resulted in a maximal underestimation of the daily column production of $2 \%$. Apparently, the use of neutral density filters will not lead to serious underestimation in waters with a relative shallow euphotic zone.

Our limited number of experiments on the size distribution of primary producers shows that earlier observations in the central North Sea (Owens et al. 1990), which showed the preponderance of primary production in the very small fraction, could not be confirmed. Therefore, generalisations about the importance of size distribution for primary production studies and foodweb studies are not yet possible. Long-term or annual time series are needed.

A comparison of our daily primary production data with other data for the same area is hampered by the lack of a consistent data set. Typical summer values are $0.065 \mathrm{~g} \mathrm{C} \mathrm{m}^{-2} \mathrm{~d}^{-1}$ for the northern North Sea (Gieskes \& Kraay 1980) and $0.7 \mathrm{~g} \mathrm{C} \mathrm{m}^{-2} \mathrm{~d}^{-1}$ for the Belgian and Dutch coastal area (Mommaerts 1973, Gieskes \& Kraay 1975, Lancelot \& Billen 1984). The value for the Dogger Bank area $\left(1.2 \mathrm{~g} \mathrm{~m}^{-2} \mathrm{~d}^{-1}\right)$ is close to the value observed for the Oyster Ground, south- east of Dogger Bank (1.0 $\mathrm{g} \mathrm{m}^{-2} \mathrm{~d}^{-1}$; Tijssen \& Wetsteyn 1984) which suggests that the southern part of the North Sea, up to the northern edge of the Dogger Bank, is characterised by relatively high primary production values during the summer.

Acknowledgements. We gratefully acknowledge the valuable contributions and suggestions of J. C. H. Peeters and the anonymous referees.

\section{LITERATURE CITED}

Anonymous (1987). The NAG Fortran library manual. Vol. 12-3. Numerical Algorithms Group Ltd., London, p. E04FDF

Asmus, H., Asmus, R. (1985). The importance of grazing food chain for energy flow and production in three intertidal sand bottom communities of the northern Wadden Sea. Helgoländer Meeresunters. 39: 273-301

Braarud, T., Ringdal Gaarder, K., Gröntved, J. (1953). The phytoplankton of the North Sea and adjacent waters in May 1948. J. Cons. perm. int. Explor. Mer 13: 5-89

Cadée, G. C. (1986). Increased phytoplankton primary production in the Marsdiep area (Western Dutch Wadden Sea). Neth. J. Sea Res. 20 (2/3): 285-290

Colijn, F. (1983). Primary production in the Ems Dollard Estuary. Thesis, Univ, of Groningen

Colijn, F., Villerius, L., Rademaker, M., Hammer, K. D., Eberlein, K. (1990). Changes in spatial distribution of primary production, photosynthetic pigments and phytoplankton species composition during two successive surveys in the German Bight. Neth. J. Sea Res. 25 (1/2): 155-164

Creutzberg, F. (1985). A persistent chlorophyll a maximum coinciding with an enriched benthic zone. In: Gibbs, P. E. (ed.) Proc. 19th Eur. Mar. Biol. Symp. Cambridge Univ. Press, Cambridge, p. 97-108

Cullen, J. J., Lewis, M. R. (1988). The kinetics of algal photoadaptation in the context of vertical mixing. J. Plankton Res. 10-5: 1039-1063

Dietrich, G. (1950). Die natürlichen Regionen von Nord- und Ostsee auf hydrographischer Grundlage. Kieler Meeresforsch. 7: 35-69

Eppley, R. W. (1972). Temperature and phytoplankton growth in the sea. Fish. Bull. U.S. 70: 1063-1085

Gieskes, W. W. C., Kraay, G. W. (1977), Primary production and consumption of organic matter in the southern North Sea during the spring bloom of 1975 . Neth. J. Sea Res, 11 (2): 146-167

Gieskes, W. W. C., Kraay, G. W. (1980). Primary productivity and phytoplankton pigment measurements in the northern North Sea during FLEX '76. 'Meteor' Forsch.-Ergebn. A-22: 105-112

Gieskes, W. W. C., Kraay, G. W. (1984). Phytoplankton, its pigments, and primary production at a central North Sea station in May, July and September 1981. Neth. J. Sea Res. 18: $51-70$

Gill, P. E., Murray, W. (1978). Algorithms for the solution of non-linear squares problem. SIAM (Soc. Ind. Appl. Math.) J. Num. Anal. 15: 977-992

Glover, H. E., Keller, M. D., Spinrad, R. W. (1987). The effects of light quality and intensity on photosynthesis and growth of marine eukaryotic and prokaryotic clones. J. exp. mar. Biol. Ecol. 105: 137-159

Harrison, W. G., Platt, T., Lewis, M. R. (1985). The utility of 
light-saturation models for estimating marine primary productivity in the field: a comparison with conventional 'simulated' in situ methods. Can. J. Fish. Aquat. Sci. 42: $864-872$

Jerlov, N. G. (1968). Optical oceanography. Elsevier, Amsterdam, p. $1-127$

Jitts, H. R. (1963). The simulated in situ measurement of oceanic primary production. Aust. J. mar. Freshwat. Res. 14: $139-147$

Jones, R. (1984). Some observations on energy transfer through the North Sea and Georges Bank food webs. Rapp. P.-v. Réun. Cons. Int. Explor. Mer 183: 204-217

Lancelot, C., Billen, G. (1984). Activity of heterotrophic bacteria and its coupling to primary production during the spring phytoplankton bloom in the Southern bight of the North Sea. Limnol. Oceanogr. 29: 721-730

Lüning, K. (1981). Light. In: Lobban, C. S., Wynne, M. J. (eds.) The biology of seaweeds. Blackwell Scientific Publ., Oxford. Bot. Monogr. 17: 326-355

Mommaerts, J.-P. (1973). On primary production in the south bight of the North Sea. Br. Phycol. J. 8: 217-231

Mortain-Bertrand, A., Descolas-Gros, C., Jupin, H. (1988). Pathway of dark inorganic carbon fixation in two species of diatoms: influence of light regime and regulator factors on diel variations. J. Plankton Res. 10: 199-217

Ochocki, S., Renk, H., Torbicki, H. (1973). Primary production and chlorophyll concentrations of the North Sea in 1973. Ann. Biol. 30: 68-70

Owens, N. J. P., Woodward, E. M. S., Aiken, J., Bellan, I. E., Rees, A. P. (1990). Primary production and nitrogen assimilation in the North Sea during July 1987. Neth. J. Sea Res. 25: $143-155$

Peterson, B. J. (1980). Aquatic primary productivity and the ${ }^{14} \mathrm{C}-\mathrm{CO}_{2}$ method: a history of the productivity problem. A. Rev. Ecol. Syst. 11: 359-389

Platt, R., Gallegos, C. L., Harrison, W. G. (1980). Photoinhibition of photosynthesis in natural assemblages of marine phytoplankton. J. mar. Res. 38: 687-701

Platt, T., Sathyendranath, S., Cavernill, C. M., Lewis, M. R. (1988). Ocean primary production and available light: further algorithms for remote sensing. Deep Sea Res. 35-6: 855-879

This article was submitted to the editor
Prézelin, B. B., Glover, H. E., Ver Hoven, B., Steinberg, D., Matlick, H. A., Schofield, O., Nelson, N., Wyman, M., Campbell, L. (1989). Blue-green light effects on lightlimited rates of photosynthesis: relationship to pigmentation and productivity estimates for Synechococcus populations from the Sargasso Sea. Mar. Ecol. Prog. Ser. 54: $121-136$

Riegman, R., Malschaert, H., Colijn, F. (1990). Primary production of phytoplankton at a frontal zone located at the northern slope of the Dogger Bank (North Sea). Mar. Biol. 105: 329-336

Smith, R. C., Bidigare, R. R., Prézelin, B. B., Baker, K. S. Brooks, J. M. (1987). Optical characterization of primary productivity across a coastal front. Mar. Biol. 96: 575-591

Sorokin, Y. I., Konovalova, I. W. (1973). Production and decomposition of organic matter in a bay of the Japan Sea during the winter diatom bloom. Limnol. Oceanogr. 18: 962-967

Spitzer, D., Wernand, M. R. (1986). Determination of spectral signatures of natural waters by optical airborne and shipborne instruments. In: Damen, M. C. J. (ed.) Proc. 7th international symposium on remote sensing for resources development and environmental management. Balkema, Rotterdam, p. 771-773

Steele, J. H. (1974). The structure of marine ecosystems. Harvard Univ. Press. Cambridge, Mass.

Steemann Nielsen, E. (1957). Experimental methods for measuring organic production in the sea. J. Cons. perm. int. Explor. Mer 144: 38-46

Tijssen, S. B., Wetsteyn, F. J. (1984). Diurnal pattern, seasonal change and variability of oxygen in the water column of the Oyster Ground (North Sea) in spring-summer 1981. Neth. J. Sea Res. 18: 13-30

Veldhuis, M. J. W., Colijn, F., Venekamp, L. A. H. (1986). The spring bloom of Phaeocyctis pouchetii (Haptophyceae) in Dutch coastal waters. Neth. J. Sea Res. 20: 37-48

Wallen, D. G., Geen, G. H. (1971). Light quality in relation to growth, photosynthetic rates and carbon metabolism in two species of marine plankton algae. Mar. Biol. 10: 34-43

Williams, P. J. leB., Robertson, J. I. (1989). A serious inhibition problem from a Niskin sampler during plankton productivity studies. Limnol. Oceanogr. 34: 1300-1305

Manuscript first received: January 8, 1990

Revised version accepted: September 18, 1990 